\title{
Histological abnormalities in the muscle spindles in rheumatoid arthritis
}

\author{
E. MAGYAR, A. TALERMAN, AND H. W WOUTERS \\ From the Departments of Pathology and Orthopaedic Surgery, Dr. Daniel den Hoed Kliniek, \\ Rotterdam, Holland
}

In rheumatoid arthritis the changes in the striated muscles, such as wasting, nodular myositis, atrophy, and degeneration, are well recognized (Curtis and Pollard, 1940; Sokoloff, Wilens, Bunim, and McEwan, 1950; Cruickshank, 1952, Wegelius, Pasternack, and Kuhlbäck, 1969; Beneke, 1972). Inflammatory and degenerative lesions of the peripheral nerves have also be described (Freund, Steiner, Leichtentritt, and Price, 1942; Radnai, 1953; Hart, Golding, and Mackenzie, 1957; Pallis and Scott, 1965). Some authors came to the conclusion, that muscle wasting, weakness, and alterations in muscle tone in rheumatoid arthritis may be due to a direct involvement of the neuro-muscular system (Morrison, Short, Ludwig, and Schwab, 1947; Moritz, 1964; Haslock, Wright, and Harriman, 1970).

In view of this we have considered that changes in the muscle spindles may be of importance and interest. Numerous authors have studied changes in the muscle spindles in various neuromuscular diseases
(Daniel and Strich, 1964; Cazzato and Walton, 1968; Patel, Lalitha, and Dastur, 1968). A review of the literature failed to reveal any studies of the morphology of muscle spindles in rheumatoid arthritis. The morphology of a normal muscle spindle was first described by Ruffini (1898). More recently it has been described in detail by Adams, Denny-Brown, and Pearson (1953), Boyd (1960), Cooper (1960), and Cooper and Daniel (1963). The muscle spindle is a highly complex sensory-motor structure, situated between the extrafusal muscle fibres, or in the perimysium (Fig. 1). It consists of a long, slender, laminated capsule of connective tissue with an endothelial lining, containing specialized striated muscle fibres (intrafusal fibres), blood vessels, and sensory motor nerve endings. The length of the capsule varies from 1 to $5 \mathrm{~mm}$. with a mean length of $3.5 \mathrm{~mm}$. In the equatorial region the maximal width is $200 \mu$. The number of intrafusal muscle fibres varies from two to fourteen.
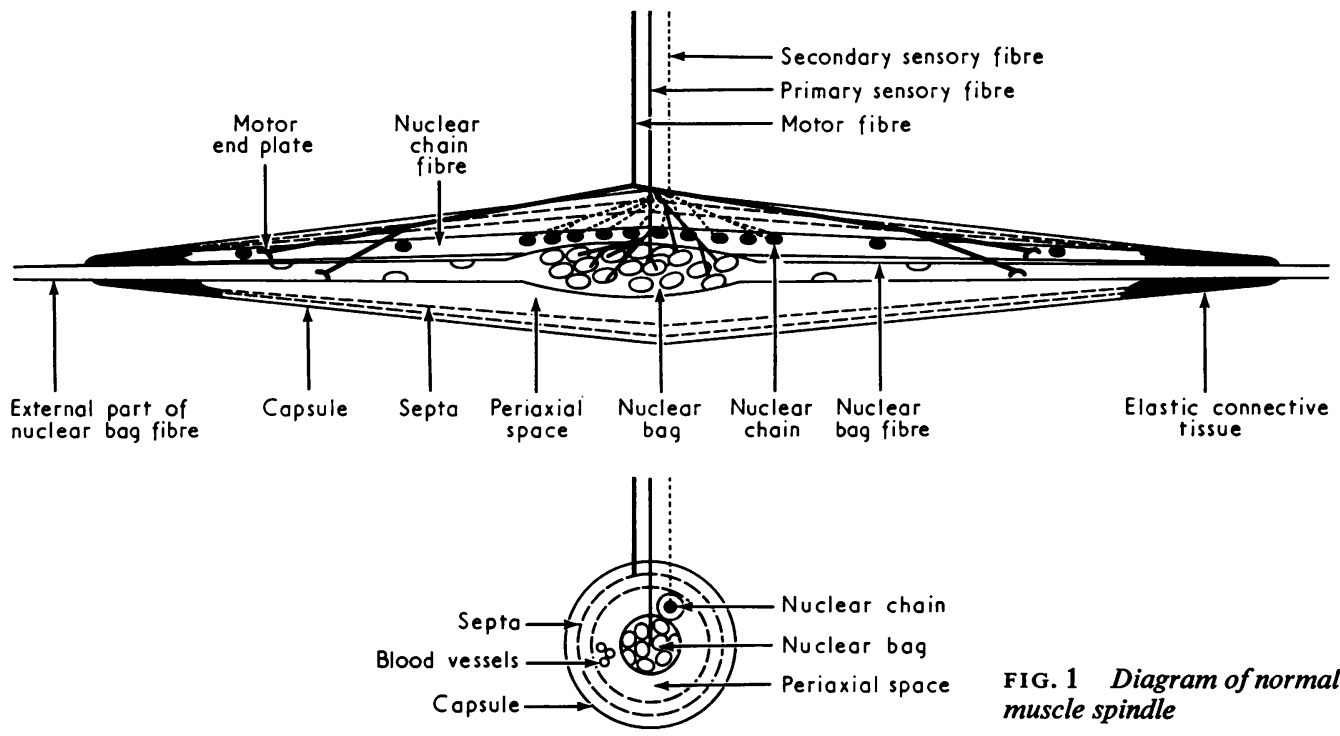

FIG. 1 Diagram of normal muscle spindle 
Two types of fibres can be distinguished:

(1) Large, or nuclear bag fibres, measuring between $15-20 \mu$ in width,

(2) small, or nuclear chain fibres, $10-15 \mu$ in width.

The nuclei of the nuclear bag fibres are large, clear, and vesicular, and are arranged in a bunch in the equatorial region of the spindle. The nuclear chain fibres have centrally placed, large, vesicular nuclei, which in the equatorial region form a chain. Between the capsule and the intrafusal muscle fibres there is a space of varying width, the periaxial space, which often contains a variable quantity of fluid of unknown composition. The sensory nerve endings are divided into two types:

(1) Primary, or annulospiral endings,

(2) Secondary, or flower-spray endings.
The primary endings encircle mainly the nuclear bag, and are found in the equatorial region of the muscle spindle. The secondary endings are found beyond the primary endings on the nuclear chain fibres. The motor nerve fibres enter the spindle together with the sensory fibres, but the end-plates are located only in the polar regions of the muscle spindle (Adams and others, 1953; Boyd, 1960, Cooper, 1960; Cooper and Daniel, 1963).

\section{Material and methods}

The present study has been carried out on biopsy material, obtained from fifty cases of rheumatoid arthritis. At operation muscle biopsies were performed mostly in a bloodless field and often from several muscles. The material from ten out of the fifty patients contained from one to nine muscle spindles suitable for examination. As controls we examined 23 muscle spindles from the same muscles,

Table Details of the cases studied

\begin{tabular}{|c|c|c|c|c|c|c|c|}
\hline $\begin{array}{l}\text { Case } \\
\text { no. }\end{array}$ & Sex & $\begin{array}{l}\text { Age } \\
(y r s)\end{array}$ & $\begin{array}{l}\text { Duration } \\
\text { of disease } \\
\text { (yrs) }\end{array}$ & Muscle biopsied & $\begin{array}{l}\text { No. of } \\
\text { spindles }\end{array}$ & $\begin{array}{l}\text { Thickness } \\
\text { of capsule }\end{array}$ & Periaxial space \\
\hline 1 & $\mathbf{M}$ & 55 & 12 & Flexor carpi ulnaris & 5 & $\begin{array}{l}\text { Normal } \\
\text { Normal } \\
++ \\
+++ \\
+++ \\
\end{array}$ & $\begin{array}{l}\text { Normal } \\
\text { Normal } \\
\text { Accumulation of fluir } \\
\text { Narrowed } \\
\text { Narrowed }\end{array}$ \\
\hline \multirow{2}{*}{2} & \multirow{2}{*}{$\mathbf{M}$} & \multirow{2}{*}{70} & \multirow{2}{*}{4} & Extensor carpi radialis & 1 & +++ & Obliterated \\
\hline & & & & Extensor digitorum communis & 1 & +++ & Obliterated \\
\hline 3 & $\mathbf{F}$ & 63 & 4 & Extensor digitorum communis & 1 & + & Accumulation of fluid \\
\hline \multirow[t]{3}{*}{4} & \multirow[t]{3}{*}{$\mathbf{F}$} & \multirow[t]{3}{*}{51} & \multirow[t]{3}{*}{8} & Indicis proprius & 6 & $\begin{array}{l}+++ \\
+ \\
++ \\
+++ \\
+++ \\
++\end{array}$ & $\begin{array}{l}\text { Obliterated } \\
\text { Accumulation of fluid } \\
\text { Obliterated } \\
\text { Obbliterated } \\
\text { Obliterated } \\
\text { Normal }\end{array}$ \\
\hline & & & & Extensor digitorum communis & 2 & $\begin{array}{l}++ \\
+++\end{array}$ & $\begin{array}{l}\text { Narrowed } \\
\text { Normal }\end{array}$ \\
\hline & & & & Obliquus abdominis & 1 & ++ & Accumulation of fluid \\
\hline 5 & $\mathbf{M}$ & 63 & 16 & Flexor carpi ulnaris & 1 & Normal & Accumulation of fluid \\
\hline 6 & $\mathbf{F}$ & 64 & 17 & Quadriceps femoris & 2 & $\stackrel{+}{++}$ & $\begin{array}{l}\text { Normal } \\
\text { Narrowed }\end{array}$ \\
\hline 7 & $\mathbf{F}$ & 64 & 33 & Abductor hallucis & 2 & $\begin{array}{l}\text { Normal } \\
+++\end{array}$ & $\begin{array}{l}\text { Accumulation of fluid } \\
\text { Narrowed }\end{array}$ \\
\hline \multirow[t]{2}{*}{8} & \multirow[t]{2}{*}{$F$} & \multirow[t]{2}{*}{54} & \multirow[t]{2}{*}{12} & Vastus medialis & 1 & Normal & Accumulation of fluid \\
\hline & & & & Vastus lateralis & 2 & $\begin{array}{l}\text { Normal } \\
+\end{array}$ & $\begin{array}{l}\text { Normal } \\
\text { Accumulation of fluid }\end{array}$ \\
\hline 9 & $\bar{F}$ & 57 & 9 & Abductor hallucis & 1 & +++ & Narrowed \\
\hline 10 & $\mathrm{~F}$ & 50 & 9 & Abductor hallucis & 1 & +++ & Narrowed \\
\hline
\end{tabular}


obtained from autopsies performed on five patients, who had died from different and unrelated diseases. Formol fixation and paraffin embedding were used. Transverse and longitudinal sections were cut from each of the muscle specimens. Numerous sections were cut, which were stained with haematoxylin and eosin, van Gieson, Masson-Goldner trichrome, and impregnated by Gomori's silver method and Holmes silver by the slide method.

\section{Results}

In all the ten patients suffering from rheumatoid arthritis, in whom muscle spindles were found, pathological changes were observed in the spindles. The Table gives a summary of our findings.

Among the 27 muscle spindles observed in these patients, only two were considered to be within normal limits (Cases 1 and 8).

\section{CAPSULE}

One of the most striking abnormalities in the spindles was fibrous thickening of the capsule. In eleven muscle spindles examined, the fibrous thickening of the capsule was assessed as marked $(+++)$ (Fig. 2, overleaf), in six as moderate $(++)$, and in four as slight $(+)$. Only six of the 27 spindles were found to have a normal, thin, and sharply-outlined connective tissue capsule.

\section{PERIAXIAL SPACE}

In eight spindles the capsular thickening was accompanied by a narrowing of the periaxial space. In three spindles the periaxial space was completely obliterated because of extensive capsular thickening. In two other cases the absence of the periaxial space was due to a proliferation of the intracapsular connective tissue. In eight spindles accumulation of eosinophilic

\begin{tabular}{|c|c|c|c|c|c|c|}
\hline Septa & $\begin{array}{l}\text { No. of } \\
\text { intrafusal } \\
\text { muscle fibres }\end{array}$ & $\begin{array}{l}\text { No. of } \\
\text { nuclear } \\
\text { bag fibres }\end{array}$ & $\begin{array}{l}\text { No. of } \\
\text { nuclear } \\
\text { chain fibres }\end{array}$ & Sarcoplasm & Nuclei & $\begin{array}{l}\text { Thickness } \\
\text { of blood } \\
\text { vessel wall }\end{array}$ \\
\hline $\begin{array}{l}\text { Normal } \\
\text { Normal } \\
\text { Broken } \\
\text { Absent } \\
\text { Absent }\end{array}$ & $\begin{array}{l}4 \\
7 \\
? \\
8 \\
2\end{array}$ & $\begin{array}{l}3 \\
2 \\
\text { Not disting } \\
3 \\
-\end{array}$ & $\begin{array}{c}1 \\
5 \\
\text { able } \\
5 \\
2\end{array}$ & $\begin{array}{l}\text { No changes } \\
\text { No changes } \\
\text { Degenerating } \\
\text { Degenerating } \\
\text { No changes }\end{array}$ & $\begin{array}{l}\text { Clumping } \\
\text { No changes } \\
\text { Pyknotic } \\
\text { No changes } \\
\text { No changes }\end{array}$ & $\begin{array}{l}+ \\
- \\
++ \\
+++ \\
+++\end{array}$ \\
\hline Absent & $?$ & \multicolumn{2}{|c|}{ Not distinguishable } & Degenerating & No changes & - \\
\hline Absent & $?$ & \multicolumn{2}{|c|}{ Not distinguishable } & Degenerating & Pyknotic & +++ \\
\hline Swollen & 1 & \multicolumn{2}{|c|}{ Not distinguishable } & Degenerating & Clumping & ++ \\
\hline $\begin{array}{l}\text { Absent } \\
\text { Broken } \\
\text { Absent } \\
\text { Absent } \\
\text { Absent } \\
\text { Broken }\end{array}$ & $\begin{array}{l}3 \\
5 \\
2 \\
4 \\
5 \\
4\end{array}$ & $\begin{array}{l}1 \\
3 \\
\text { Not distin } \\
\text { Not disting } \\
\text { Not disting } \\
2\end{array}$ & $\begin{array}{l}2 \\
2 \\
\text { abble } \\
\text { able } \\
\text { able } \\
2\end{array}$ & $\begin{array}{l}\text { Degenerating } \\
\text { No changes } \\
\text { Degenerating } \\
\text { No changes } \\
\text { No changes } \\
\text { Degenerating }\end{array}$ & $\begin{array}{l}\text { Absent } \\
\text { Pyknotic } \\
\text { Pyknotic } \\
\text { Absent } \\
\text { Pyknotic } \\
\text { No changes }\end{array}$ & $\begin{array}{l}++ \\
+++ \\
++ \\
++ \\
++ \\
++\end{array}$ \\
\hline $\begin{array}{l}\text { Absent } \\
\text { Absent }\end{array}$ & $\begin{array}{l}2 \\
6\end{array}$ & \multicolumn{2}{|c|}{$\begin{array}{l}\text { Not distinguishable } \\
2\end{array}$} & $\begin{array}{l}\text { No changes } \\
\text { Degenerating }\end{array}$ & $\begin{array}{l}\text { Absent } \\
\text { Pyknotic }\end{array}$ & $\begin{array}{l}++ \\
+\end{array}$ \\
\hline Broken & 2 & \multicolumn{2}{|c|}{ Not distinguishable } & $\begin{array}{l}\text { Myogenic } \\
\text { giant cells }\end{array}$ & Pyknotic & - \\
\hline Normal & 一 & \multicolumn{2}{|l|}{ Absent } & Absent & Absent & - \\
\hline $\begin{array}{l}\text { Normal } \\
\text { Swollen }\end{array}$ & $\begin{array}{l}7 \\
2\end{array}$ & $\begin{array}{l}2 \\
2\end{array}$ & 5 & $\begin{array}{l}\text { Degenerating } \\
\text { No changes }\end{array}$ & $\begin{array}{l}\text { Pyknotic } \\
\text { Pyknotic }\end{array}$ & $\stackrel{+}{-}$ \\
\hline $\begin{array}{l}\text { Broken } \\
\text { Swollen }\end{array}$ & $?$ & \multicolumn{2}{|c|}{$\begin{array}{l}\text { Not distinguishable } \\
5\end{array}$} & $\begin{array}{l}\text { Necrotic } \\
\text { No changes }\end{array}$ & $\begin{array}{l}\text { Clumping } \\
\text { No changes }\end{array}$ & $\overline{+}++$ \\
\hline Broken & 2 & \multicolumn{2}{|c|}{ Not distinguishable } & Degenerating & Clumping & +++ \\
\hline $\begin{array}{l}\text { Normal } \\
\text { Broken }\end{array}$ & 3 & 2 & 1 & $\begin{array}{l}\text { No changes } \\
\text { Absent }\end{array}$ & $\begin{array}{l}\text { No changes } \\
\text { Absent }\end{array}$ & $\overline{+}++$ \\
\hline Broken & 3 & \multicolumn{2}{|c|}{ Not distinguishable } & No changes & Pyknotic & $++t$ \\
\hline Absent & 2 & \multicolumn{2}{|c|}{ Not distinguishable } & No changes & Pyknotic & - \\
\hline
\end{tabular}




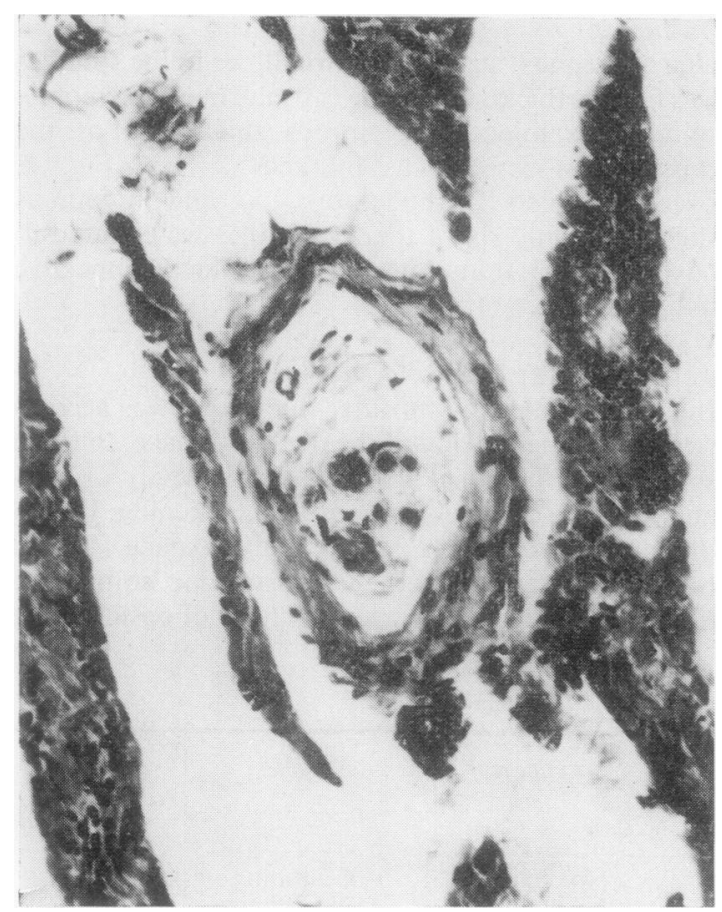

FIG. 2 Muscle spindle, showing marked thickening of the fibrous capsule. $\times 140$

fluid within the periaxial space was seen, causing dislocation of the intrafusal muscle fibres (Fig. 3). In six spindles the periaxial space was considered to be normal.

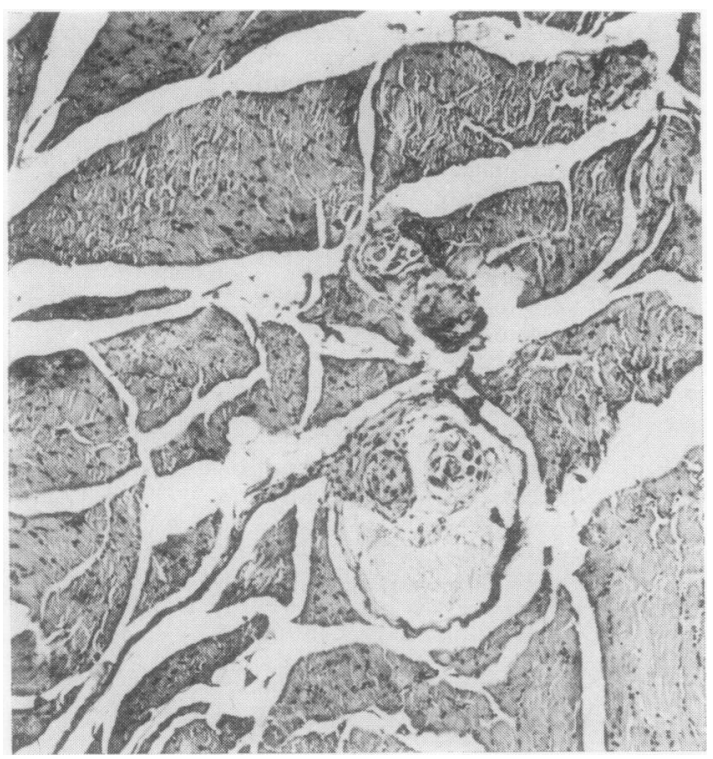

FIG. 3 Muscle spindle showing accumulation of fluid in the periaxial space and dislocation of intrafusal muscle fibres. $\times 54$
SEPTA

In eleven spindles with marked capsular thickening, the fibrous septa of the periaxial space were absent, and in eight other spindles they seemed to be broken up and decreased in number. In three spindles these septa were swollen, and in only five did they have a normal sharp outline with a concentric lamellar structure, and an obvious endothelial lining.

Both in the equatorial and in the polar regions, and between the equator and the poles of the muscle of spindles, capsular thickening with considerable reduction of the periaxial space was present, as well as diminution, or total absence of the connective tissue septa.

INTRAFUSAL FIBRES

We observed considerable abnormalities in the number of intrafusal muscle fibres and pathological iv changes in their sarcoplasm and their nuclei.

In the present cases the number of the intrafusal muscle fibres varied from 0 to 8 , with a mean of 2.96 . In two muscle spindles, no muscle fibres could be found, but only some pale structureless material, staining yellow with van Gieson and pink with Masson-Goldner trichrome (Fig. 4). In nine of the

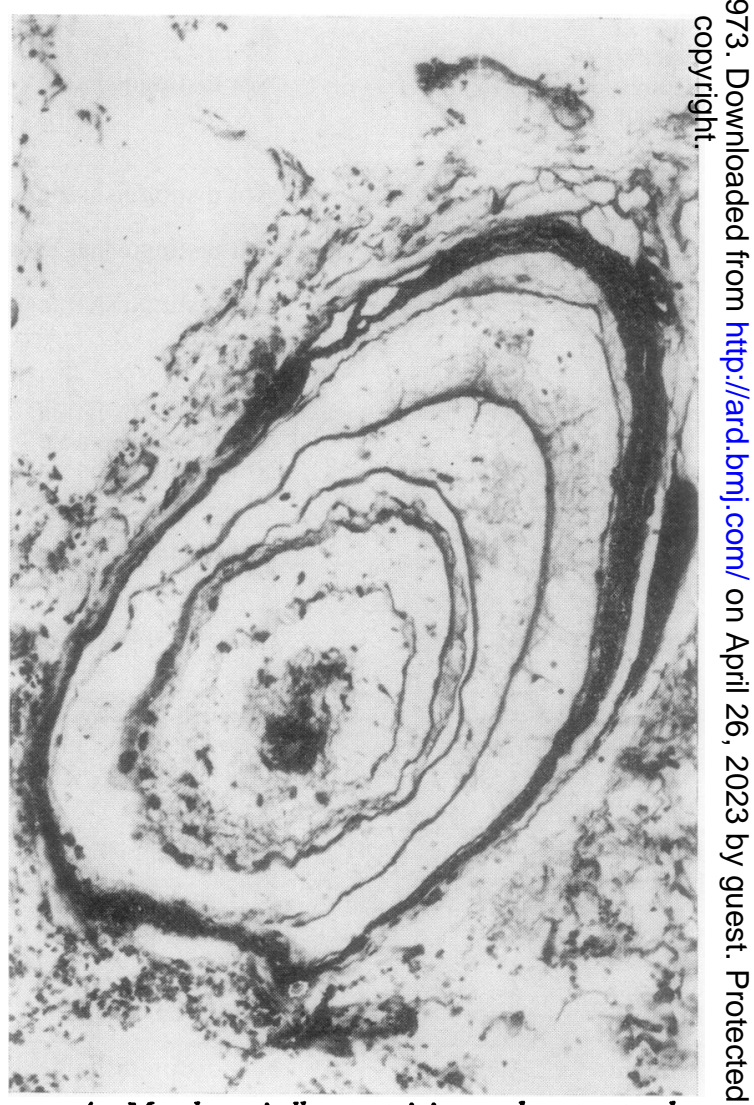

FIG. 4 Muscle spindle containing pale structureless material and devoid of muscle fibres. $\times 350$

( $\vec{\omega}$ 을 
27 spindles, atrophy of all the fibres was so marked that it was not possible to distinguish the nuclear bag fibres from the nuclear chain fibres. In four other spindles it was not possible to count, or even to recognize the intrafusal fibres, which were fragmented and had coalesced. In twelve muscle spindles it was possible to determine the type of intrafusal fibres. The number of the nuclear bag fibres varied from 0 to 5 (mean 2.25). The number of nuclear chain fibres varied from 0 to 5 (mean $2 \cdot 41$ ).

In twelve spindles the histological appearances of the sarcoplasm of the intrafusal muscle fibres were considered to be within normal limits. In spite of the fact that in these cases marked atrophy of the muscle fibres was sometimes present, their cross-striation was well preserved. The intrafusal muscle fibres of eleven spindles showed signs of degenerative changes, such as homogenization, granular desintegration, vacuolization, increased eosinophilia, and pallor of the sarcoplasm (Fig. 5). Necrosis of the intrafusal muscle fibres was evident in one spindle. In another spindle myogenic giant cells were observed and this was considered as evidence of destruction of intrafusal muscle fibres.

\section{NUCLEI}

In all except seven of the muscle spindles both the nuclei of the nuclear bag fibres and of the nuclear chain fibres showed extensive changes. The large, vesicular, clear nuclei became shrunken, very dark, and pyknotic. They had lost their normal arrangement and were irregularly distributed with formation

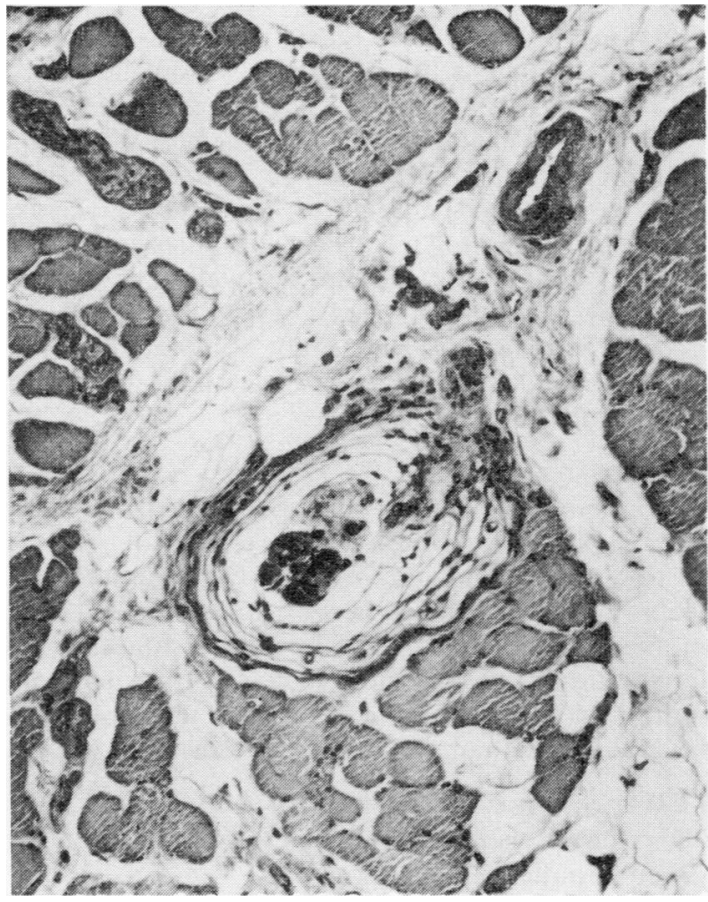

FIG. 6 Muscle spindle showing an irregular distribution of the nuclei of the intrafusal muscle fibres and nuclear clumping. $\times 140$

of big nuclear clumps, which were present mainly in the equatorial region of the spindles (Fig. 6).

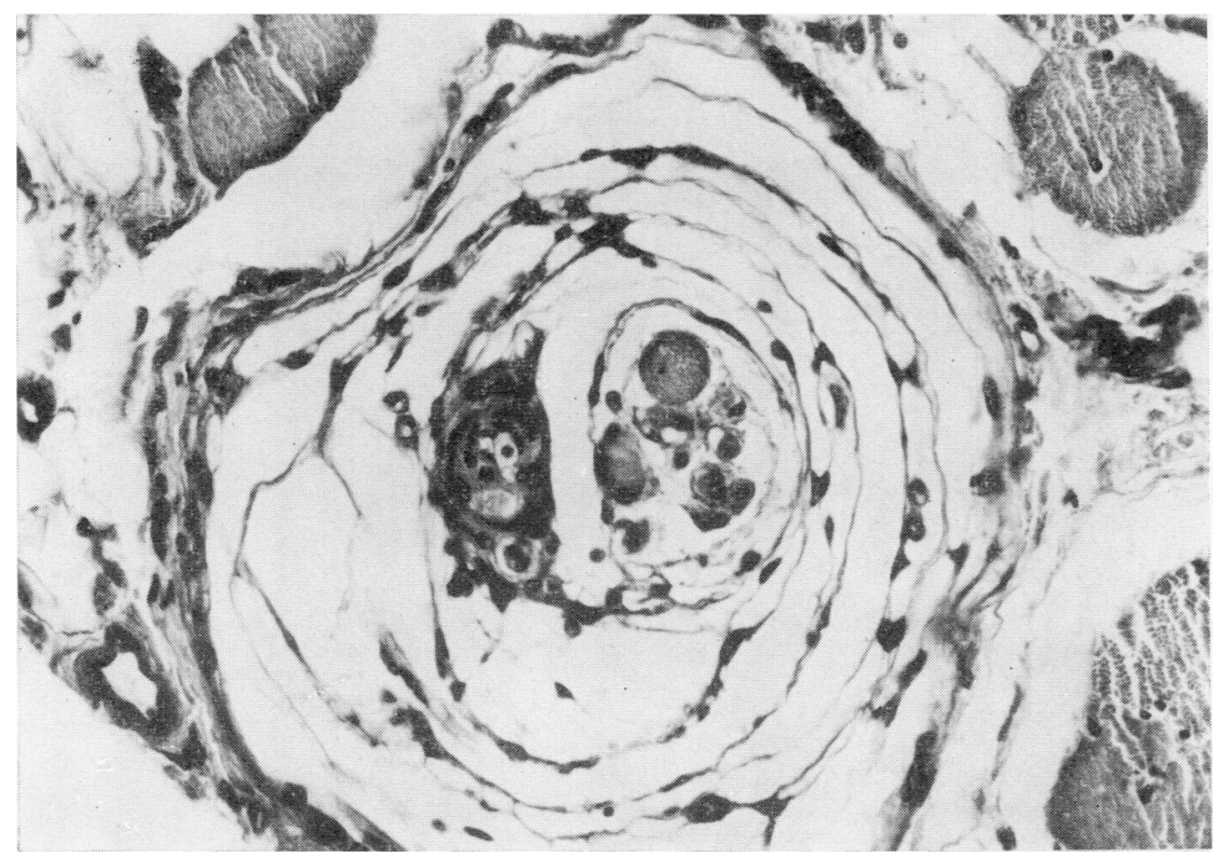

FIG.5 Muscle spindle showing degeneration and vacuolization of intrafusal fibres and thickening of walls of blood ressels within the spindle. $\times 385$ 


\section{VESSELS}

In eight specimens the capillaries within the muscle spindles showed marked thickening of the walls $(+++)$, with hyalinization and marked narrowing, or even (Icclusion of the lumen. Furthermore nine spindles contained vessels with moderate thickening of the wall $(++)$, and a considerable narrowing of the lumen. In two other spindles the wall of the vessels was only slightly thickened $(+)$ and the lumen was normal. In the remaining eight spindles the capillaries were not suitable for examination, or were not detected.

\section{INNER VATION}

The innervation of muscle spindles is very complex, and the presence of abnormalities is difficult to assess. In some cases our observations were incomplete for technical reasons and some we were not able to study in more detail. We have the impression that the innervation of the muscle spindles, both sensory and motor, was often completely absent, and only some fragmental remnants of the nerve fibres were present.

LYMPHOCYTIC INFILTRATION

This was observed in three muscle spindles from two different patients (Fig. 7).

CHANGES IN THE MUSCLES

The extrafusal muscle fibres of the ten patients studied showed marked changes. There was denervation atrophy, nodular myositis with extended lymphorrhages, and evidence of degenerative changes in muscle fibres. There was an increased amount of perimysial and epimysial connective tissue, and the blood vessels found in it were thick-walled, often showing endarteritis obliterans. Subacute, proliferative arteritis was also observed. Marked changes were found in the nerve bundles within the striated muscle. There was a marked increase in the amount of interstitial connective tissue, as well as thickening of the endo- peri- and epineurium.

\section{Discussion}

The results of our study show that in cases of rheumatoid arthritis abnormalities of the muscle spindles are frequent. They manifest themselves as capsular thickening, and alterations in the periaxial space and in the connective tissue septa. Quantitative and qualitative changes of the intrafusal muscle fibres as well as marked thickening of the wall of the blood vessels and damage to the innervation are also present. The majority of these abnormalities are similar to those of denervation changes affecting the muscle spindles.

The behaviour of the muscle spindle in denervated muscle has been studied both clinically and experi mentally. Onanoff (1890) and Horsley (1897) observe $\$$ marked atrophy of the intrafusal muscle fibres after. denervation of muscle in the dog. Batten (1897) found significant alterations in the small nerve fibres to the spindles. Tower (1932), using cats, found that when

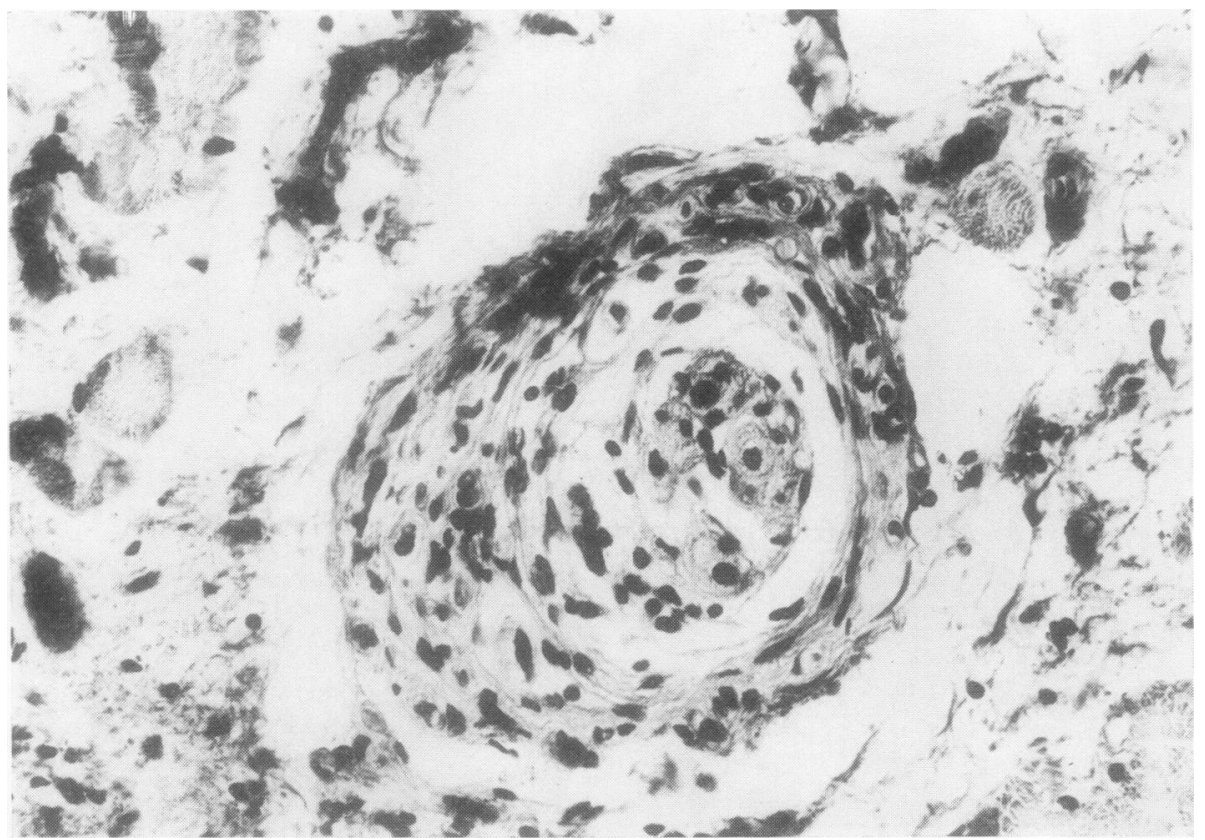

FIG. 7 Muscle spindle showing marked thickening of the fibrous capsule, decrease of the periaxial space, and slight lymphocytic infiltration. $\times 385$ 
the whole nerve supplying a muscle was cut, the capsule of the muscle spindles became thickened and the intracapsular connective tissue increased. The intrafusal muscle fibres became thinner and showed degenerative changes. If the dorsal (sensory) roots were cut, then only the equatorial region of the spindles was affected. There was marked reduction in the number and size of the nuclei of the nuclear bag, and degeneration of the intracapsular nerve fibres. When the ventral (motor) roots were cut, degenerative changes in the intrafusal muscle fibres were present in the polar regions and the equatorial part remained intact. Sunderland and Ray (1950), studying the denervation changes in striated muscle, concluded that the intrafusal muscle fibres shared in the atrophic changes involving the extrafusal fibres, but not to the same degree. Lapresle and Milhaud (1964) found significant changes in the muscle spindles in cases of sensory-motor polyneuropathy. Wohlfart (1949) also observed degenerative changes in advanced cases of polyneuritis. Cazzato and Walton (1968) studied the behaviour of the muscle spindles in muscle biopsies obtained from fourteen cases of denervation atrophy. They observed alterations in the connective tissue capsule, periaxial space, and connective tissue septa, as well as in the intrafusal muscle fibres. Patel and others (1968) reported similar findings.

It is suggested that in rheumatoid arthritis the changes in the muscle spindles, as well as those in the extrafusal muscle fibres, may be due to a generalized vasculitis. These vascular changes in the peripheral nerves are frequent, sometimes causing severe peripheral neuropathy (Radnai, 1953; Irby, Adams, and Toone, 1958; Pallis and Scott, 1965). Electromyographic evidence of denervation and lesions of the lower motor neurone have been detected in some cases (Steinberg, 1960; Moritz, 1964; Haslock and others, 1970).

Apart from the denervation there is also a considerable chronic hypoxia of the muscle tissue due to the vasculitis and progressive thickening of the blood vessels within the muscle (Oka, Rekonen, and Elomaa, 1971). The disturbances in the function of the muscle spindles caused by hypoxia have been described by Matthews (1933) and Göpfert and Schaeffer (1941). The presence of necrosis of the intrafusal muscle fibres as well as that of myogenic giant cells in our material may be due to deficient circulation.

\section{Summary}

The muscle spindles were studied in muscle biopsies obtained at operation in ten cases of rheumatoid arthritis. Abnormal changes were observed in nearly all muscle spindles examined. The abnormalities consisted of marked thickening of the capsule of the spindle, loss of periaxial space, decrease in number in the intrafusal muscle fibres, degenerative changes in the intrafusal muscle, and thickening of the wall and narrowing of the lumen of the blood vessels. This indicates that in rheumatoid arthritis the muscle spindles are affected by the disease and show a considerable degree of abnormality. It is suggested that, in rheumatoid arthritis, changes in the muscle spindles as well as those in the extrafusal muscle fibres may be due to a generalized vasculitis.

\section{References}

adams, R. D., Denny-Brown, P., and Pearson, C. M. (1953) 'Diseases of Muscle'. Cassell, London, Toronto, Melbourne, Sydney, and Wellington.

BATTEN, F. E. (1897) Brain, 20, 138 (The muscle spindle under pathological conditions)

Beneke, G. (1972) Verhandl. dtsch. Ges. Rheumatol., Band 2, p. 142 (Die Reaktion des Muskelbindegewebes bei rheumatischen Erkrankungen). [Z. Rheumaforsch. 31, Suppl. 2]

Boyd, I. A. (1960) J. Physiol. (Lond.), 153, 23P (The diameter and distribution of the nuclear bag and nuclear chain muscle fibres in the muscle spindles of the cat)

Cazzato, G., and Walton, J. N. (1968) J. neurol. Sci., 7, 15 (The pathology of the muscle spindle. Study of biopsy material in various muscular and neuromuscular diseases)

COOPER, S. (1960) 'Muscle spindles and other muscle receptors', in 'The Structure and Function of Muscle', ed. G. H. Bourne, vol. 1, pp. 381-420. Academic Press, New York, London.

- AND Daniel, P. M. (1963) Brain, 86, 563 (Muscle spindles in man; their morphology in the lumbricals and the deep muscles of the neck)

Cruickshank, B. (1952) J. Path. Bact., 64, 21 (Focal lesions in skeletal muscles and peripheral nerves in rheumatoid arthritis and other conditions)

Curtis, A. C., AND Pollard, H. M. (1940) Ann. intern. Med., 13, 2265 (Felty's syndrome: its several features, including tissue changes, compared with other forms of rheumatoid arthritis)

Daniel, P. M., AND Strich, S. J. (1964) Neurology (Minneap.), 14, 310 (Abnormalities in the muscle spindles in dystrophia myotonica)

Freund, H. A., Steiner, G., Leichtentritt, B., ANd Price, A. E. (1942) Amer. J. Path., 18, 865 (Peripheral nerves in chronic atrophic arthritis)

GÖPFERT, H. AND SCHAEFFER, H. (1941) Verh. dtsch. Ges. Kreislaufforsch. xiv. Tagung, p. 119 (Der Einfluss der Anoxämie auf die periphere Motorik) 
Hart, F. Dudley, Golding, J. R., AND Mackenzie, D. H. (1957) Ann. rheum. Dis., 16, 471 (Neuropathy in rheumatoid disease)

Haslock, D. I., Wright, V., AND Harriman, D. G. F. (1970) Quart. J. Med., 39, 335 (Neuromuscular disorders in rheumatoid arthritis. A motor-point muscle biopsy study)

HoRSLEY, V. (1897) Brain, 20, 375 (Short note on sense organs and on the preservation of muscle spindles in conditions of extreme muscular atrophy, following section of the motor nerve)

Irby, R., AdAms, R. A., AND ToONE, E. C., JR. (1958) Arthr. and Rheum., 1, 44 (Peripheral neuritis associated with rheumatoid arthritis)

LaPResle, J., AND Milhaud, M. (1964) Rev. neurol., 110, 97 (Pathologie du fuseau neuro-musculaire)

Matthews, B. H. C. (1933) J. Physiol. (Lond.), 78, 1 (Nerve endings in mammalian muscle)

Moritz, U. (1964) Acta rheum. scand., 10, 99 (Studies on motor nerve conduction in rheumatoid arthritis)

Morrison, L. R., Short, C. L., Ludvig, A. O., AND Schwab, R. S. (1947) Amer. J. med. Sci., 214, 33 (The neuromuscular system in rheumatoid arthritis)

Oka, M., ReKonen, A., AND ElomaA, I. (1971) Acta rheum. scand., 17, 203 (Muscle blood flow in rheumatoid arthritis)

ONANOFf, I. (1890) C.R. Soc. Biol. (Paris), $9^{\mathrm{e}}$ sér., 2, 432 (Sur la nature des faisceaux neuro-musculaires)

Pallis, C. A., AND ScotT, J. T. (1965) Brit. med.J., 1, 1141 (Peripheral neuropathy in rheumatoid arthritis)

Patel, A. N., Lalitha, V. S., AND Dastur, D. K. (1968) Brain, 91, 737 (The spindle in normal and pathological muscle. An assessment of the histological changes)

RadnaI, B. (1953) Acta morphol. Acad. Sci. Hung., 3, 87 (Vascular changes in peripheral nerves and skeletal muscles in rheumatoid arthritis)

Ruffini, A. (1898) J. Physiol. (Lond.), 23, 190 (On the minute anatomy of the neuromuscular spindles of the cat, and on their physiological significance)

Sokoloff, L., Wilens, S. L., Bunim, J. J., ANd McEwen, C. (1950) Amer. J. med. Sci., 219, 174 (Diagnostic value of histologic lesions of striated muscle in rheumatoid arthritis)

Steinberg, V. L. (1960) Brit. med.J., 1, 1600 (Neuropathy in rheumatoid disease)

Sunderland, S., AND Ray, L. J. (1950) J. Neurol. Neurosurg. Psychiat., 13, 159 (Denervation changes in mammalian striated muscle)

Tower, S. S. (1932) Brain, 55, 77 (Atrophy and denervation in the muscle spindle)

Wegelius, O., Pasternack, A., AND KUHLBäCK, B. (1969) Acta rheum. scand., 15, 257 (Muscular involvement in rheumatoid arthritis)

Wohlfart, G. (1949) Arch. Neurol. Psychiat., 61, 599 (Muscular atrophy in diseases of the lower motor neuron) 